\title{
Reducing the EU's Global Environmental Footprint
}

\author{
Joanne $\operatorname{Scott}^{*}$
}

\section{A. Introduction}

The EU has a large and damaging global environmental footprint, and as a region it is heavily dependent on environmental resources that originate outside its borders. This Article begins by illustrating the scale of the EU's global environmental footprint. It goes on to demonstrate that the EU has been commendably proactive in generating the data needed to evaluate this. It has also adopted a series of measures that seek to mitigate the negative external-third countryenvironmental effects of EU consumption. Though measures of this kind are sometimes controversial, it is argued that the EU is justified in adopting them. Such measures nonetheless give rise to difficulties and dilemmas which the EU ought not to ignore.

\section{B. The EU's Global Environmental Footprint}

Perhaps the most widely known data source shedding light on the environmental footprints of nations and regions is generated by the Global Environmental Footprint Network. ${ }^{1}$ This source provides information on the Ecological Footprint of countries and regions, which is a measurein hectares - of the ecological assets they require to produce the resources they consume and the waste they generate. It includes built-up land, carbon footprint, cropland, grazing land, forest land, and fishing ground. The Environmental Footprint data set also compares the Ecological Footprint of countries and regions with their biocapacity in order to ascertain the scale of a region or country's Ecological Surplus or Deficit. Table 1 shows the global average Ecological Footprint and Biocapacity and compares this to that of Western Europe in $2016 .{ }^{2}$ On the basis of this data, it is estimated that approximately 1.7 planets would be required to sustain current global consumption patterns, whereas almost 3 planets would be required to sustain current consumption patterns within Western Europe if these consumption patterns were to be replicated globally. ${ }^{3}$ The presence of an Ecological Deficit is important, because-as the Ecological Footprint Network

${ }^{\star}$ Professor of European Law at the European University. The author is very grateful to Professor Stefam Giljum for his generous help in providing data to assist with this Article.

${ }^{1}$ Global Footprint Network: Advancing the SCIENCE OF Sustainability, http://data.footprintnetwork.org/\#/ (last visited Oct. 28, 2019).

${ }^{2}$ Table 1 understates the scale of the anthropogenic ecological deficit, because it ignores the fact that human beings must share their environment with wild species which also place ecological demands on the planet.

${ }^{3}$ Within the EU-28, Luxembourg and Estonia had the highest Ecological Footprint per capita in 2016, 12.9 hectares and 7.1 hectares respectively. In contrast, Hungary and Bulgaria have the lowest, 3.6 and 3.4 respectively. Only four EU-28 Member States have an ecological surplus when their Ecological Footprint and biological capacity are compared. According to a report by WWF, the EU-28's planetary demands are slightly lower than those of "Western Europe"-undefined in Global Environmental Footprint dataset-with the EU-28 requiring 2.8 as opposed to 2.98 planets if its consumption patterns were replicated worldwide. This also reports that the EU-28 uses $20 \%$ of the world's biocapacity, with $7 \%$ of the world's population. See World Wildlife Fund's Global Footprint Network: Advancing the Science Sustainability, Eu overshoot DAY: Living Beyond Nature's Limits 7, 17 (2019).

(C) The Author(s) 2020. Published by Cambridge University Press on behalf of the German Law Journal. This is an Open Access article, distributed under the terms of the Creative Commons Attribution licence (http://creativecommons.org/licenses/by/4.0/), which permits unrestricted re-use, distribution, and reproduction in any medium, provided the original work is properly cited. 
Table 1: The Ecological Footprint and Biocapacity of Western Europe and the World Compared

\begin{tabular}{lll}
\hline & Ecological Footprint per capita & Biocapacity per capita \\
\hline Global & 2.75 hectares & 1.63 hectares \\
\hline Western Europe & 4.86 hectares & 1.78 hectares \\
\hline
\end{tabular}

states - this "means that the nation is importing biocapacity through trade, liquidating national ecological assets, or emitting carbon dioxide waste into the atmosphere."4

Another dataset known as EXIOBASE 3.4 measures the environmental footprints of countries and regions, focusing on their material footprint, carbon footprint, water footprint, and land footprint. ${ }^{5}$ This dataset is also consumption-based and identifies which environmental pressures are generated outside of the country where the products are consumed. The dataset compares territorial emissions and resource extractions with global environmental footprints and reveals the extent to which countries or regions are dependent upon emissions and extractions of environmental resources in other countries or regions. Table 2 below summarizes the EU-28's per capita environmental footprint, compares this to the global average, and shows what percentage of each footprint category is comprised of non-territorial emissions or extractions. Non-territorial emissions or extractions of environmental resources are labeled as "foreign share." The table shows that "Europe is currently living on emission and resource credits provided by other parts of the world." Indeed, it is more dependent than any other world region on foreign environmental resources. ${ }^{7}$

\section{The EU's Role in Generating Data Regarding Its Global Environmental Footprint}

The EU has been commendably active in increasing awareness of the EU's global environmental footprint and in increasing the availability of reliable data to support policy initiatives aiming to reduce that footprint. For example, the EU has contributed financially to the development of EXIOBASE by offering support from its research framework programs. ${ }^{8}$ Further, Eurostat, which is the statistical office of the European Union, has participated in efforts at the international level to develop international standards for environmental accounting. ${ }^{9}$ These international standards are being gradually implemented within the EU, providing a harmonized framework for the collection of environmental data by Member States. ${ }^{10}$ This data includes economy-wide material flow

\footnotetext{
${ }^{4}$ See Global Footprint Network: Advancing the Science of Sustainability, supra note 1 (emphasis added).

${ }^{5}$ EXIOBASE, https://www.exiobase.eu (last visited Oct. 28, 2019). EXIOBASE is a global Multi-Regional Environmentally Extended Supply-Use Table and Input-Output Table that measures and analyzes the environmental impacts associated with the final consumption of products. Material footprint comprises the extraction of abiotic raw materials-fossil fuels, metals, and non-metallic minerals-and biotic raw materials from agriculture, forestry, and fisheries.

${ }^{6}$ Arnold Tukker et al., Environmental and Resource Footprints In a Global Context: Europe's Structural Deficit In Resource Endowments, 40 GLOBAL ENVTL. CHANGE 171, 179 (2016).

${ }^{7}$ WU (2018): Own Calculation based on EXIOBASE 3.4. This data was provided to the author by Professor Stefan Giljum, Vienna University of Economics and Business.

${ }^{8}$ About EXIOBASE, EXIOBASE, https://www.exiobase.eu/index.php/about-exiobase. EXIOBASE was developed by a consortium of several research institutes in projects financed by the European research framework programs.

${ }^{9}$ See What is the SEEA?, Sys. ENVTL. ECON. ACCT., https://seea.un.org/content/homepage (last visited Oct. 28, 2019) (stating that the System for Environmental and Economic Accounting is a statistical system that was developed and rolled out by the UN Statistics Division, Eurostat, FAO, OECE, IMF, and World Bank Group).

${ }^{10}$ See Environmental Accounts - Establishing the Links Between the Environment and the Economy, EUROSTAT, https://ec.europa. eu/eurostat/statistics-explained/index.php/Environmental_accounts_-_establishing_the_links_between_the_environment_and_ the_economy (highlighting that "[e]nvironmental accounts are a statistical system bringing together economic and environmental information in a common framework"); 2011 O.J. (L 192) 1, http://data.europa.eu/eli/reg/2011/691/2014-06-16.
} 
Table 2: The EU-28's per capita global environmental footprint including percentage derived from non-territorial emissions/extractions

\begin{tabular}{lcccc}
\hline & Materials & (Blue) Water & Land & Carbon \\
\hline EU per capita & $25.2 \mathrm{t} / \mathrm{cap}$ & $226 \mathrm{~m}^{3} / \mathrm{cap}$ & $0.02 \mathrm{~km}^{2} / \mathrm{cap}$ & $13.2 \mathrm{t} / \mathrm{cap}$ \\
\hline Global per capita & $11.8 \mathrm{t} / \mathrm{cap}$ & $150 \mathrm{~m}^{3} / \mathrm{cap}$ & $0.008 \mathrm{~km}^{2} / \mathrm{cap}$ & $5.4 \mathrm{t} / \mathrm{cap}$ \\
\hline EU foreign share & $38 \%$ & $64 \%$ & $31 \%$ & $25 \%$ \\
\hline
\end{tabular}

accounts (EW-MFAs) which measure material flows into and out of an economy-covering solid, gaseous, and liquid materials, except for bulk flows of water and air. ${ }^{11}$ These accounts do not, however, include materials that are used in the production of goods but which are not physically transported between economies. The European Statistical System Committee has recently adopted a new European Strategy for Environmental Accounts 2019-2023, which aims to further develop and promote the use of environmental accounts. ${ }^{12}$

Equally pertinent have been the EU's efforts to develop methodologies to calculate product and organization environmental footprints. ${ }^{13}$ Building upon existing methodologies, the Commission has published guidance on how to develop product and organization environmental footprint "category rules" to be used in calculating a product or organization's environmental impacts using a lifecycle approach. ${ }^{14}$ The processes for developing these rules were tested and implemented in a pilot phase that concluded in 2018. Moving forward, the Commission will consider how product and environmental footprints can be used in EU policy. As things stand, it has emphasized that "the use of [these footprints] is voluntary, therefore, it will not act as a restriction on international trade." 15

In parallel with the environmental footprint project, the Commission has also been developing new indicators to assess the lifecycle environmental impacts that emerge from the consumption of goods and services within the EU. ${ }^{16}$ The Consumer Footprint assesses the environmental impacts of an average EU citizen based on the consumption of goods in five areas-food, mobility, housing, household goods, and appliances. The Consumption Footprint quantifies the environmental impacts associated with total EU consumption, taking account of impacts relating both to domestic activities and trade. These indicators cover sixteen categories of environmental impacts including water use, climate change, land use, and resource use like fossil fuels, minerals, and metals. ${ }^{17}$ Consistent with the findings presented above, the Commission's study reveals that the EU is a "net importer of environmental impacts" and that the consumption of an average EU citizen is "outside the safe operating space for humanity," in relation to climate, particulate matter, resource use, freshwater eutrophication, and human-toxicity cancer. ${ }^{18}$

\footnotetext{
${ }^{11}$ See Eurostat, supra note 10 (providing an overview of the different types of environmental accounts).

${ }^{12} 39$ th Meeting of the European Statistical Committee, Eur. STAT. Sys. COMMITTEE, 1 (Feb. 7, 2019), https://ec.europa.eu/ eurostat/documents/1798247/6191525/European+Strategy+for+Environmental+Accounts/.

${ }^{13}$ See generally Single Market for Green Products Initiative, Eur. Commission, (Jul. 8 2019), https://ec.europa.eu/ environment/eussd/smgp/index.htm.

${ }^{14}$ European Commission, Guidance document: Guidance for the development of Product Environmental Footprint Category Rules, (Dec. 15, 2017) (version 6.3); European Commission, Guidance document: Guidance for the development of Organisation Environmental Footprint Sector Rules, (Jan. 12 2018) (version 6.3).

${ }^{15}$ See Eur. Commission, supra note 13, at "Questions and Answers."

${ }^{16}$ Serenella Sala, et al., Indicators and Assessment of the Environmental Impact of EU Consumption, JOINT RESEARCH CENTER SCIENCE FOR POLICY REPORT 2 (2019).

${ }^{17}$ For the full list, see id. at $9-10$.

${ }^{18} I d$. at 3 .
} 
Table 3: EU Environmental Measures Giving Rise to Territorial Extension

\begin{tabular}{|c|c|c|c|c|c|}
\hline $\begin{array}{l}\text { Policy } \\
\text { domain }\end{array}$ & Forests & Fisheries & Waste & Climate & General \\
\hline \multirow[t]{4}{*}{ Instruments } & \multirow[t]{4}{*}{$\begin{array}{l}\text { Legality verification } \\
\text { of imported timber } \\
\text { (Reg. 2173/2005 \& } \\
\text { Reg. 995/2010) }\end{array}$} & $\begin{array}{l}\text { Preventing the } \\
\text { importation of } \\
\text { illegally caught fish } \\
\text { (IUU) Reg. 1005/2008) }\end{array}$ & $\begin{array}{l}\text { Waste } \\
\text { shipments (Reg. } \\
\text { 1013/2006) }\end{array}$ & $\begin{array}{l}\text { Including aviation in } \\
\text { GHG emissions } \\
\text { trading scheme } \\
\text { (Dir. 2008/101) }\end{array}$ & \multirow[t]{4}{*}{$\begin{array}{l}\text { Green public } \\
\text { procurement } \\
\text { (Dir. 2014/24 } \\
\& \text { 2014/25) }\end{array}$} \\
\hline & & \multirow[t]{3}{*}{$\begin{array}{l}\text { Excluding non- } \\
\text { sustainably sourced } \\
\text { fish (Reg. 1026/2012) }\end{array}$} & $\begin{array}{l}\text { Exports of } \\
\text { electrical and } \\
\text { electronic waste } \\
\text { (Dir. 2012/19) }\end{array}$ & $\begin{array}{l}\text { Monitoring, } \\
\text { reporting and } \\
\text { verifying shipping } \\
\text { emissions (Reg. } \\
2015 / 757 \text { ) }\end{array}$ & \\
\hline & & & $\begin{array}{l}\text { Recycling EU- } \\
\text { flagged ships } \\
\text { (Reg. 1257/2013) }\end{array}$ & $\begin{array}{l}\text { Sustainability } \\
\text { criteria for biofuels } \\
\text { (Dir. 2009/ } 28 \text { \& Dir. } \\
\text { 2009/30) }\end{array}$ & \\
\hline & & & & $\begin{array}{l}\text { Reduction of } \\
\text { lifecycle emissions } \\
\text { from transport fuels } \\
\text { (Dir. 2009/30) }\end{array}$ & \\
\hline
\end{tabular}

\section{Using Trade-Related Measures Giving Rise to "Territorial Extension" to Address the EU's Global Environmental Footprint}

There are many different mechanisms that can be used to reduce the EU's global environmental footprint. While multilateral environmental agreements - that are substantively ambitious, widely ratified, and effectively enforced - offer the most effective means of mitigating the negative environmental effects of economic activity globally, such agreements are increasingly hard to achieve. It is also the case that even multilateral environmental agreements that adopt a consumptionbased perspective do not tend to address environmental resources that are embodied—but not physically incorporated-into traded goods.

In view of this, the $\mathrm{EU}$ has adopted a wide range of trade-related measures which seek to reduce the scale or mitigate the negative impacts of the EU's global environmental footprint. These measures give rise to "territorial extension" in that while their application is triggered by the existence of a territorial connection with the $\mathrm{EU}$, they seek to regulate conduct that takes place outside of the EU. ${ }^{19}$ The principal examples of EU environmental measures giving rise to territorial extension are identified in Table 3 above.

There are many different ways in which to categorize or draw distinctions between these measures. For example, while some seek to enforce existing international standards, others embody standards that have been established unilaterally by the EU. ${ }^{20}$ Although most of these measures aim to protect global or transboundary environmental resources, those governing the export of waste aim principally to protect the environment and human health within third countries. Although some regulate individual shipments of products, others render compliance conditional on the content of third country law.

It is notable that many of the measures included in Table 3 rest upon standards which are defined qualitatively rather than quantitatively. For example, timber imported into the EU must

\footnotetext{
${ }^{19}$ For a full discussion, see JoAnne Scott, The Global ReaCh of EU Environmental LaW 21-63 (Joanne Scott \& Marise Cremona eds., 2019).

${ }^{20}$ Some fall in between in that the EU is implementing international standards that have not yet entered into force.
} 
be legally harvested. Imported fish must not be derived from illegal, unreported, or unregulated fishing. Waste that is exported from the EU to a third country must be subject to environmentally sound treatment. With measures like these, the EU is seeking to reduce the negative effects that flow from each unit of EU consumption, rather than reducing the volume of EU consumption itself.

Even to the extent that the measures included in this table are premised upon quantitative as opposed to qualitative standards, they take the form of environmental intensity standards which seek to improve environmental efficiency rather than limit the total volume of EU consumption. This can be exemplified by the fuel quality directive-included in the penultimate column of Table 3-which seeks to reduce the GHG intensity of road transport fuels by a minimum of $6 \%$ by 2020 . This directive, however, does not introduce any absolute limit on the volume of road transport fuels consumed. In addition, the EU's decision to include aviation in its greenhouse gas (GHG) emissions trading scheme (ETS) may look like an outlier in this respect, in that it imposes an absolute annual cap on the volume of emission allowances issued for aviation. Nonetheless, it remains open to airlines to purchase emission allowances from other sectors of the economy that are included in the ETS. Thus, while the ETS does establish an absolute cap on GHG emissions for all covered sectors taken collectively, it does not impose an absolute cap on aviation emissions as such. ${ }^{21}$

We will return briefly to the distinction between quality and quantity below.

\section{E. Should the EU Enact Measures Giving Rise to Territorial Extension?}

EU measures giving rise to territorial extension have sometimes proved to be controversial. Never has this been more true than in relation to the EU's decision to include international aviation in the ETS. This measure united much of the world in opposition to the EU, leading it to suspend its application to all flights except those internal to the EEA. It did so pending possible international agreement to tackle aviation emissions within the International Civil Aviation Organization (ICAO). In 2016, ICAO adopted a Carbon Offsetting and Reduction Scheme for International Aviation (CORSIA). ${ }^{22}$ This scheme aims to stabilize $\mathrm{CO}_{2}$ emissions from international aviation at 2020 levels by requiring airlines to offset emissions above this level. Unfortunately, as things stand, this international scheme is lacking in both credibility and ambition. Unless this changes, the EU will be faced with a difficult decision about whether to reinstate the full geographical scope of its aviation directive with the result that it would apply to all EU-arriving and departing flights.

The EU's fuel quality directive also provoked strong opposition from powerful countries and industries. ${ }^{23}$ The directive states that the required reduction in GHG emissions is to be measured by reference to lifecycle emissions and calculated according to a methodology to be elaborated by the European Commission. The Commission's proposed methodology established a "default value" for GHG emissions from different kinds of fuel, including a default value for fuel derived from bitumen ("tar sands") that was $22 \%$ higher than that for conventional crude oil. This value reflected the higher upstream emissions associated with this fuel source due to the extra energy that is required to extract and refine it. Although the Commission was reported to have resisted pressure from the tar sands industry early in the process, ultimately, the Commission's

\footnotetext{
${ }^{21}$ In fact, even the absolute cap for all covered sectors has been compromised by the availability of carbon offsets deriving from projects in third countries. Nonetheless, the EU does not envisage allowing the use of such international credits after 2020, at which point the EU's cap may be considered to constitute an absolute limit on GHG emissions from ETS covered sectors collectively. See Use of international credits, EuR. COMMISsION WEBsiTe, https://ec.europa.eu/clima/policies/ets/ credits_en.

${ }^{22}$ Resolution A39-3: Consolidated statement of continuing ICAO policies and practices related to environmental protectionGlobal Market-based Measure (MBM) scheme, International Civil Aviation Organization (Sep. 27-Oct. 7, 2016).

${ }^{23}$ For a good overview, see A Fact-Finding Trip to the Core of the Fuel Quality Directive, TrANSPORT \& ENVIRONMENT, 1-9 (July 2013), https://www.transportenvironment.org/sites/te/files/publications/Tarsands_briefing_T\%26E_final.pdf.
} 
methodology for calculating the lifecycle emissions of transport fuels was not adopted. Both Canada and the United States were very active in communicating their opposition to it. As things stand - and contrary to the Commission's proposed methodology—current EU default values for transport fuels do not distinguish between conventional and high-carbon source fuels. The EU is now importing heavy blend crude oil that is derived from highly polluting tar sands.

Although sometimes controversial, it is my contention that measures giving rise to territorial extension can be justified to reduce the scale and impact of the EU's global environmental footprint. Such measures can help enforce existing international standards and can also encourage progress in negotiations leading to the multilateral environmental agreements. The EU's willingness to step aside pending the conclusion of an international agreement - in the aviation example and elsewhere-shows that it is acting as a contingent unilateralist or a unilateralist of last resort.

Measures giving rise to territorial extension may also be necessary to prevent the EU from being complicit in environmental wrongdoing that takes place in third countries. Where the EU permits the importation of fish or timber that have been illegally harvested, or sanctions the export of hazardous waste in circumstances where this may pose a threat to human health or the environment, the EU is making a potentially essential causal contribution to environmental wrongdoing. ${ }^{24}$ Where the EU has - or could reasonably be expected to have-knowledge of this wrongdoing, it emerges not as an innocent bystander but as a morally culpable, complicit actor. The increasing availability of reliable data concerning the EU's global environmental footprint makes it more likely that this condition will be met.

Though measures that aim to reduce the EU's global environmental footprint may be justified, they also give rise to difficulties and dilemmas which it would be politically foolhardy and morally inappropriate to ignore.

European countries have a long history of colonialism, which in the 19th and early 20th centuries resulted in their controlling around one-fifth of global land surface. ${ }^{25}$ This period of European colonialism wrought widespread environmental destruction, the consequences of which are still suffered in many developing countries today. The late colonial period also witnessed technocratic conservation efforts which often excluded and further impoverished indigenous communities.

Further, and not unconnected to the ecological legacy of European colonialism, trade-related measures giving rise to territorial extension - which aim to mitigate environmental harm occurring in third countries - often negatively affect poor countries and poor communities. These measures entangle the EU in "socio-ecological conflicts," which involve trade-offs between different groups. $^{26}$

As things stand, the EU is not always sufficiently attentive to the distributive consequences of the measures it adopts to mitigate its global environmental footprint. It is frequently the case that the impact assessments that are prepared prior to the adoption of these measures focus more upon possible negative impacts within the EU than on those occurring abroad. It is incumbent on the EU to take steps to evaluate more carefully_-and to seek to mitigate-the negative consequences of its measures where these will be suffered by those least equipped to endure them. Contrary to what is sometimes claimed, it is open to the EU to adopt trade measures that differentiate between countries. Reasoned differentiation to reflect economic and social differences between and within countries does not necessarily amount to unlawful discrimination. It is notable that when the EU adopts environmental measures that apply within the EU, these measures are often imbued with a degree of flexibility to permit regional and national differences to be taken into account.

\footnotetext{
${ }^{24}$ For a fuller explication of this argument, see SCOTT, supra note 19; see also CHIARA LEPORA \& ROBERT E. GOODIN, ON COMPLICITY AND COMPROMISE (2013).

${ }^{25}$ Corey Ross, Ecology and Power in the Age of Empire: Europe and the Transformation of the Tropical WORLD 3 (2017).

${ }^{26}$ For a discussion from this perspective in a policy domain covered by an EU measure giving rise to territorial extension, see Federico Demaria, Shipbreaking at Alang-Sosiya (India): An Ecological Distribution Conflict, 70 ECOLOGICAL ECON. 250 (2010).
} 
Finally, as noted previously, EU measures giving rise to territorial extension aim to reduce the damaging effects or environmental intensity of EU consumption rather than reducing the level of consumption itself. Recalling that almost three planets would be required to sustain current levels of consumption within Western Europe, it is clear that absolute reductions in consumption are also required. This reality will necessitate changes in the ways in which products are designed, produced, used, and recycled in an increasingly "circular economy," ${ }^{27}$ but it will also require a more fundamental repudiation of our "empire of things." 28

\footnotetext{
${ }^{27}$ On the EU's policies in relation to the circular economy, see Circular Economy: Implementation of the Circular Economy Action Plan, Eur. Commission (Jul. 8, 2019), https://ec.europa.eu/environment/circular-economy/index_en.htm.

${ }^{28}$ Frank Trentmann, Empire of Things: How We Became a World of Consumers, From the Fifteenth Century TO THE TWENTY FIRST (2013).
}

Cite this article: Scott J (2020). Reducing the EU's Global Environmental Footprint. German Law Journal 21, 10-16. https:// doi.org/10.1017/glj.2019.88 